\title{
Discipline Levels of Junior Students during Physical Education Lessons at Schools
}

\author{
Eddy Marheni ${ }^{1, *}$, Eko Purnomo ${ }^{1,2}$, Nina Jermaina ${ }^{2}$, Afrizal S. ${ }^{1}$, Surya Rezeki Sitompul ${ }^{3}$, I Kadek \\ Suardika $^{2,4}$, Faradifta Tirta Ardita ${ }^{1}$
}

\author{
${ }^{1}$ Faculty of Sports Science, Universitas Negeri Padang, Padang, 25132, West Sumatra, Indonesia \\ ${ }^{2}$ Doctoral Program of Sports Education, School Postgraduates Studies, Universitas Pendidikan Indonesia, Bandung, 40154, West Java, \\ Indonesia \\ ${ }^{3}$ Sport Education, Universitas Negeri Jakarta, Jakarta, 13220, East Jakarta, Indonesia \\ ${ }^{4}$ Sports and Health Education Program, STKIP Agama Hindu Singaraja, Singaraja, 81119, Buleleng, Bali, Indonesia
}

Received April 16, 2021; Revised April 26, 2021; Accepted May 22, 2021

\section{Cite This Paper in the following Citation Styles}

(a): [1] Eddy Marheni, Eko Purnomo, Nina Jermaina, Afrizal S., Faradifta Tirta Ardita, I Kadek Suardika, "Discipline Levels of Junior Students during Physical Education Lessons at Schools," International Journal of Human Movement and Sports Sciences, Vol. 9, No. 4, pp. 635 - 641, 2021. DOI: 10.13189/saj.2021.090405.

(b): Eddy Marheni, Eko Purnomo, Nina Jermaina, Afrizal S., Faradifta Tirta Ardita, I Kadek Suardika(2021). Discipline Levels of Junior Students during Physical Education Lessons at Schools. International Journal of Human Movement and Sports Sciences, 9(4), 635 - 641. DOI: 10.13189/saj.2021.090405.

Copyright@2021 by authors, all rights reserved. Authors agree that this article remains permanently open access under the terms of the Creative Commons Attribution License 4.0 International License

\begin{abstract}
This research is based on the importance of student discipline in learning at school. In this study, the authors conducted a quantitative research using the pre-experimental design type one group pretest-posttest method. One group pretest-posttest design is a research activity that provides a pre-test before being given treatment, after being given treatment then gives a final test (post-test). The sample of this research was 50 students of class XII Vocational High School 1 Bangkinang. This study was analyzed using a quantitative descriptive technique. The study results as a whole are that there was an increase in the level of student discipline by $9.11 \%$ with the acquisition of pre-test scores of $76.68 \%$ and post-test of $85.78 \%$. The results explained an increase in the level of student discipline when given physical education learning treatment. The score is still considered very low and needs to be improved so that later students have a high discipline level. One of the most effective ways to improve student disciplinary behavior at schools is to carry out physical activity. This research still has shortcomings and weaknesses; namely, the research was conducted in just one month. This allows further researchers to carry out research to improve student discipline for a longer time.
\end{abstract}

Keywords Discipline Levels, Lessons Physical Education, Junior Student

\section{Introduction}

Physical education has an essential role in developing students' abilities [1], including discipline it. Student disciplinary issues disproportionately affect urban schools with many low-income and ethnic minority students [2]. There is growing information on positive behavioral support from exclusive corrective strategies to promote a more positive classroom environment [3]. Many students attending public schools exhibit disciplinary issues such as disruptive classroom behavior, vandalism, intimidation, and violence [4].

Student discipline is a problem that is often encountered at school [5]. The issue of student discipline in schools is a problem that researchers often face. The environment is a strong influence on student discipline. Problems that also affect students' discipline are also from the family [6]. Establishing effective disciplinary practices is essential to ensure academic success and provide a safe learning environment [4].

Participating children mostly regard discipline as a phenomenon that guides their behavior, maintains order, and is necessary for social life [7]. The punishment given 
by the school has not provided a deterrent effect. Penalties that are negative due to disciplinary errors can fix student disciplinary problems and are likely to occur in the future can be reduced or will not even happen again [8]. Suppose students want to learn effectively and efficiently. In that case, students must first be aware of their sense of personal responsibility and believe that learning is for their benefit and is something that is done and does not depend on others. Students' discipline and motivation become the basis for achievement because discipline and motivation are the basis for achievement, especially in economic learning.

Discipline has a positive role in student achievement. This requires all stakeholders' involvement in the school environment to apply discipline consistently and provide various motivations that can further improve achievement results [9]. Also, there are differences in male and female students' level of discipline, where female students tend to have a higher discipline level than men [10]. With a disciplined attitude, students can use practical learning methods, which are also an excellent character-building process. So that these attitudes can later create a good feeling and influence learning achievement. Apart from discipline, other elements forming the character from outside also greatly influence student learning outcomes (natural environment, economy, social conditions, and the school environment). Therefore, school control is very influential on student achievement.

Factors that affect student discipline implementation include internal student factors, school environment factors, attention factors, and parenting patterns (family) [11]. The family's involvement (parents) is very close and essential for the child's welfare and development in the future. Family is the primary cell of society where childcare begins at birth [12]. One of the most appropriate ways to improve student discipline is to adopt a military system involving army and Police personnel as trainers to foster the habit of greeting and respecting students when meeting with others [13]. In addition to the teaching and family factors, the school's system can provide and improve student discipline [11].

Physical education is considered the main subject for analyzing student behavior [14]. As it turns out, the way physical education teachers teach affects character [15] and student discipline level [16]. Physical education learning reveals positive results (discipline and academic performance in Physical Education) [17]. Education becomes more efficient if teachers use strategies that allow students to have a reason to maintain their discipline in the classroom [18]. The educational process is a comprehensive growth for individuals in improving all aspects of students [19]. Meanwhile, the unique nature of physical education is that it can increase students' level of discipline through physical activities and influence increasing the ability of physical health, in general, to carry out daily activities. [20]. The process of physical education at schools is one of the essential components in supporting learning success. Therefore, it is necessary to develop its empowerment and organization, to achieve the desired objectives [21].

The problem that currently still occurs in Indonesian education is that physical education for the XII grade Vocational High School level is not included in the material that must be taught by schools in the Basic Framework and Structure of the 2013 Vocational High School Curriculum. physical education can be carried out and how it impacts on student discipline.

Regarding student discipline problems in schools, physical education can be a near or far-term plan to improve student discipline in school [22], [23].

The results showed that quality relationships with peers, teachers, and parents made a big difference to students, especially those trying to build strong social skills (including discipline) [24]. The school environment is an essential factor related to individual differences in self-control [25]. The question in this article is, what is the level of discipline of students while in school?

\section{Materials and Methods}

This type of research uses quantitative research. Quantitative research is research that describes or explains a problem whose results can be generalized. Thus it does not place too much importance on data depth or analysis. While the research method used is the descriptive method, a research method that describes the population under study and consists of variables.

Assessment using a Likert scale (1-5).The result of adopting an instrument made by Keith Davis (1985).The assessment indicators are eight items, with each item having five items/questions so that the total number of items/questions is 40 .

\subsection{Population and Sample}

The population was all students at Vocational High School 1 Bangkinang. While the sample was taken using the purposive sampling method with male students as the sample. The reason for using only male students is the small number of female students.The ratio between male and female students in this school is 10: 1.So that if female students are still included in the sample, the data will not be homogeneous.This reason is the guide for this sampling.

The sample of this research was 50 students of class XII Vocational High School 1 Bangkinang.

\subsection{Procedure}

Before conducting this research, the researcher first permitted the school to conduct research. Furthermore, the researcher made a disciplinary measurement research instrument (Keith Davis, 1985). After that it is validated and tested. The research begins by creating a learning 
program outside school hours. This is done because students do not have time to study physical education during school lessons.

Researchers designed simple learning to carry out physical activities and activities. Learning that is created by utilizing games (through football, basketball, and athletics) emphasizes social elements and increases physical fitness. Learning in this study was carried out for one month. In one week, the treatment is carried out three times and starts from 15.00-17.00. The activities carried out can also make students more relaxed and relaxed due to boredom while studying in the classroom.

Table 1. Student Disciplinary Competencies

\begin{tabular}{ccl}
\hline No & Competencies & \multicolumn{1}{c}{ Description } \\
\hline 1 & $\begin{array}{c}\text { Discipline in } \\
\text { time }\end{array}$ & $\begin{array}{l}\text { Time discipline is related to the number } \\
\text { of class attendance and also the } \\
\text { punctuality of attending physical } \\
\text { education learning at school. }\end{array}$ \\
2 & $\begin{array}{c}\text { Discipline in } \\
\text { learning in the } \\
\text { classroom } \\
\text { Discipline in } \\
\text { collecting tasks } \\
\text { Neatness } \\
\text { discipline in } \\
\text { dress }\end{array}$ & $\begin{array}{l}\text { Attude discipline in participating in } \\
\text { Discipline that emphasizes punctuality in } \\
\text { doing and collecting assignments } \\
\text { Discipline in wearing clothes while in the } \\
\text { field (learning physical education) }\end{array}$ \\
& $\begin{array}{c}\text { Discipline in } \\
\text { conduct }\end{array}$ & $\begin{array}{l}\text { Discipline related to behavior and daily } \\
\text { behavior at school }\end{array}$ \\
\hline
\end{tabular}

\subsection{Data Analysis}

The data analysis technique is a technique for obtaining conclusions on the problem being researched, so data analysis techniques are essential in a study. The data collected, if not processed, will not get meaningful conclusions before an analysis of existing data is carried out.

The data from the questionnaire in this study are quantitative data which will be analyzed descriptively in percentage with the following steps:

a) Calculate the value of the respondent and each aspect or sub variable.

b) Recap value.

c) Calculate the average value.

d) Calculate the percentage with the formula:

$$
P=\frac{\sum X i}{\sum X n}
$$

Information:

$\mathrm{P}=$ amount or amount of percentage

$\sum \mathrm{Xi}=$ Total actual score

$\sum \mathrm{Xn}=$ Maximum number of scores

\section{Results}

From the results of the study conducted for one month, the authors obtained and grouped data from the application of student discipline and supporting factors can be seen in Table 1 below:

Table 2. Student disciplinary research results (pre and post test)

\begin{tabular}{|c|c|c|c|c|c|}
\hline No & Indicators & Pre-test & Category & Post-test & Category \\
\hline 1. & $\begin{array}{l}\text { Discipline } \\
\text { in time }\end{array}$ & $83,9 \%$ & Good & $91,3 \%$ & Excellent \\
\hline 2. & $\begin{array}{l}\text { Discipline } \\
\text { in learning } \\
\text { in the } \\
\text { classroom }\end{array}$ & $77,4 \%$ & Good & $80,1 \%$ & Good \\
\hline 3. & $\begin{array}{l}\text { Discipline } \\
\text { in } \\
\text { collecting } \\
\text { tasks }\end{array}$ & $71 \%$ & Good & $80 \%$ & Good \\
\hline 4. & $\begin{array}{c}\text { Neatness } \\
\text { discipline } \\
\text { in dress }\end{array}$ & $93,5 \%$ & Excellent & $94 \%$ & Good \\
\hline 5. & $\begin{array}{l}\text { Discipline } \\
\text { in conduct }\end{array}$ & $57,6 \%$ & $\begin{array}{l}\text { Less } \\
\text { Good } \\
\end{array}$ & $83,5 \%$ & Good \\
\hline \multicolumn{2}{|c|}{ Average } & $76,68 \%$ & Good & $85,78 \%$ & Good \\
\hline
\end{tabular}

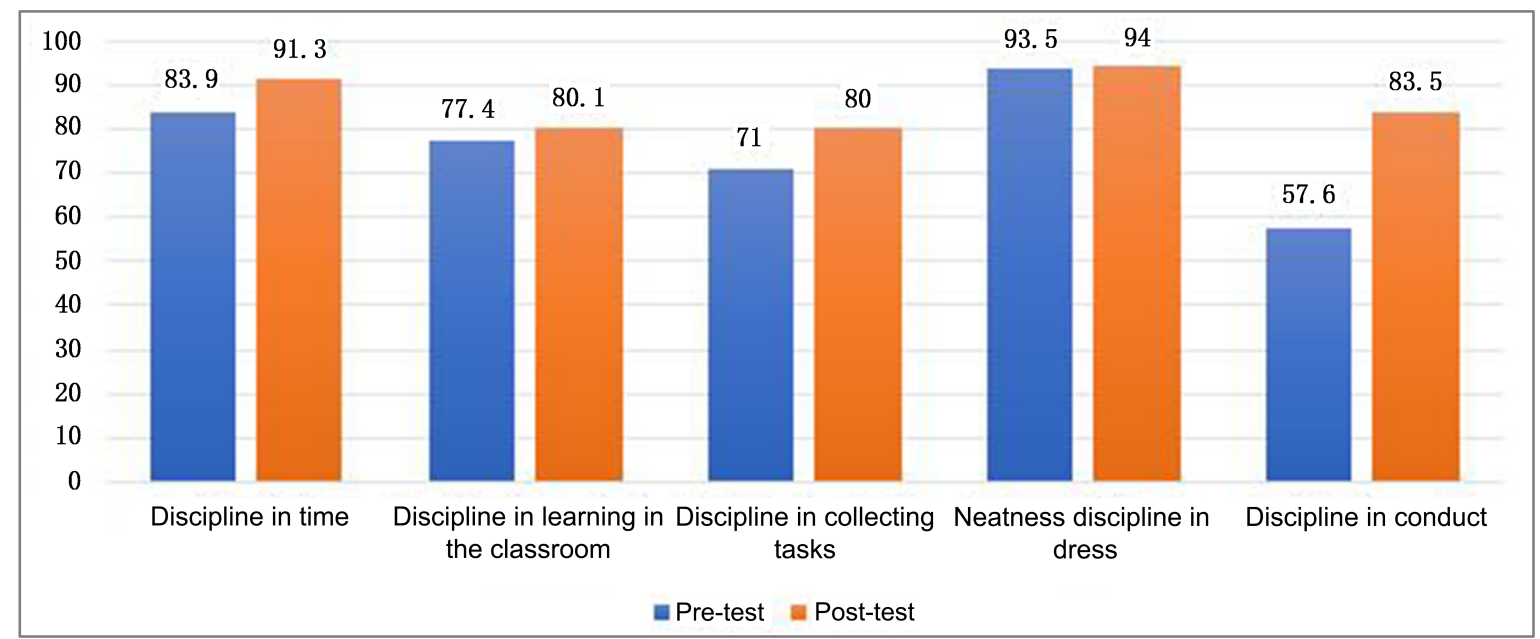

Figure 1. Student disciplinary research results (pre and post test) 
In table and figure 1, Although the overall results did not change to be perfect, the scores obtained increased from $76.68 \%$ (pre-test) to $85.78 \%$ (post-test). These results indicate that physical education can improve student discipline. This is considered very important because discipline plays a vital role in the process of self-control. Self-control plays a crucial role in the development of children and adolescents [25]. Schooling is an essential factor associated with individual differences in self-control. Good self-control will make individuals behave disciplined [26]. Meanwhile, racial disparities in school disciplines remain at the heart of discussions around school discipline [27].

\subsection{Discipline in Time}

Time discipline scored $91.3 \%$ (post-test) of the acquisition before treatment $83.9 \%$ (pre-test). The pre-test results show that there are still (16.1\%) students who arrive late. There was at least a $7.4 \%$ increase in the results of the treatments performed during this study. Student indiscipline occurs because individuals do not value time, or students are not taught the importance of discipline and time appreciation since childhood. Because in fact the discipline that is applied in school can shape students' character to be better [28]. Schools can shape students as desired or even become worse (distorted) [8], [29], [30]. Because they don't value time, things don't go well, sometimes because someone is often late or lacks discipline.

\subsection{Discipline in Learning in Class}

Before disciplinary treatment in classroom learning, the score was $77.4 \%$. These results indicate that there are still students who do not realize the importance of education. Also, students must appreciate the teacher who explains the material in front of the class. And some students talk with their peers, daydream, don't listen, eat and drink casually while the teacher is explaining the material in class. Apart from breaking discipline, it also makes students less ethical towards teachers. Comparison of the assessment (post-test) after the treatment obtained a value of $80.1 \%$ in the good category. These results only add $2.7 \%$ improvement in the level of student discipline in-class learning. Punishment in appropriate and consistent schools can improve adolescents' pro-social outcomes for the better [31]. Teachers should be more appropriate in reprimanding and giving sanctions to students who are not disciplined in class to provide punishment and focus more on learning and listening to teacher explanations. Also, of the many aspects that affect student discipline, school discipline is considered an essential factor that effectively develops students' self-control capacity [25].

\subsection{Discipline in Collecting Tasks}

From these data, it can be seen that the discipline in collecting assignments is $71 \%$ (pre-test) and the increase is $80 \%$ (post-test). This means that students are aware of the assignment and collect it according to a predetermined schedule (on time). Timeliness in submitting this assignment is an important indicator and an integral part of the service. This will later be related to job responsibilities/assignments given.

\subsection{Neatness Discipline in Dress}

Discipline in dress got $93.5 \%$ (pre-test) and increased to 94\% (post-test).The score obtained shows that the students are very suitable in dressing by school rules and regulations, including using appropriate clothing while carrying out physical education learning.This encourages and supports the reason that discipline is one of the essential components of human behavior. It can be said that without this discipline, an institution cannot function properly, including in the field of clothing [32].

\subsection{Discipline in Conduct}

Discipline in behavior reached $57.6 \%$ (pre-test) to $83.5 \%$ (post-test). This point can be interpreted that students who behave well are students who are educated and cultured as well. But unfortunately, many students consider this matter trivial. Nearly $50 \%$ of students do not pay attention and do not notice that behavioral behavior is also an important thing to do. The provision of treatment during this study seems to make students more aware of being better at behaving. The social drive in sporting activities (sportsmanship, honesty, fair play) can make students behave better.

\section{Discussion}

Classrooms are student communities where formal interactions occur between teachers and students [33]. Teachers play an essential role in shaping the character of students (religion, Pancasila, culture, and educational goals [34]) in a better future, including discipline [35]. One of the most significant disciplinary supports is in oneself (70.8\%) in the data obtained. The application of this discipline is like following a fair learning process. This self-awareness can encourage individuals to do something better, including improving achievement at school. The key elements to support students' success are schools that communicate care and incorporate flexibility into their learning. [36].

A good student with teacher relationships can also result in better student circumstances and reduce teachers' fear in schools [37]. Therefore, there must be a good relationship between the student with teachers to improve student discipline. The low level of specialization of school students can also impact the sustainability of students [38]. Also, the interview results stated that there 
was an influence on the level of discipline from parental support. The level of parental education significantly affects students' perceptions of good behavior [32]. This shows that there is still a lack of support from parents and the environment for students to increase discipline level and even indicates that parents and the environment do not show or exemplify student disciplinary behavior. Due to adolescents' nature, they observe and imitate people associated with them in the social context and normative factors sent by the group [39]. Therefore, parents must behave and apply discipline to children at home because harmonious intervention between parents and children's interactions depends on their adaptive social behavior [40].

Their playmates can also influence the actual level of student discipline. In this case, the friendship network's similarities focus on the individual's attitudes and behaviors visible in a context where the choice to make friends is relatively unrestricted [41]. Interactions between peers can have a positive impact, but often peers bring negative influences [42]. Many students do the right thing because they are affected by their peers. Therefore, students like this need special attention from parents and teachers. Physical education is also an integral part of education that plays a vital role in students' overall well-being [43], including discipline.

\section{Conclusion}

Finally, we found tremendous results in improving student discipline. Parents, teachers, peers, and the environment in providing ideas, concepts, examples of behaviors, and essential norms in life have a profound impact and influence on the success that significantly improves student discipline. Also, field and self-determination reject adverse effects that often appear to be a significant factor in enhancing the area. In this study, problems can be solved in the following research, namely on gender and family status differences in student discipline.

\section{Research Limitations}

The researcher realizes that the research being carried out is still lacking, especially in the program being carried out. The study was only conducted for one month with three meetings each week. Researchers understand that discipline with a brief amount of your time permits pseudo-discipline to occur. This implies that students solely mate once being supervised by a man of science or teacher. Later analysis encourages analysis with an extended amount of your time so that automation will occur in student disciplinary behavior.

\section{Acknowledgments}

The authors would like to thank Lembaga Penelitian dan Pengabdian Masyarakat Universitas Negeri Padang for funding this work with a contract number: 1388/UN35.13/LT/2020.

\section{REFERENCES}

[1] T. Muhtar, T. Supriyadi, and A. S. Lengkana, "Character development-based physical education learning model in primary school,” Int. J. Hum. Mov. Sport. Sci., vol. 8, no. 6, pp. 337-354, 2020, doi: 10.13189/saj.2020.080605.

[2] L. H. Brown and K. S. Beckett, "The role of the school district in student discipline: Building consensus in Cincinnati,” Urban Rev., vol. 38, no. 3, pp. 235-256, 2006, doi: 10.1007/s11256-006-0032-8.

[3] M. M. Mitchell and C. P. Bradshaw, "Examining classroom influences on student perceptions of school climate: The role of classroom management and exclusionary discipline strategies,” J. Sch. Psychol., vol. 51, no. 5, pp. 599-610, 2013, doi: 10.1016/j.jsp.2013.05.005.

[4] J. K. Luiselli, R. F. Putnam, M. W. Handler, and A. B. Feinberg, "Whole-school positive behaviour support: Effects on student discipline problems and academic performance," Educ. Psychol., vol. 25, no. 2-3, pp. 183-198, 2005, doi: $10.1080 / 0144341042000301265$.

[5] I. Ibabe, "Academic failure and child-to-parent violence: Family protective factors,” Front. Psychol., vol. 7, no. OCT, pp. 1-11, 2016, doi: 10.3389/fpsyg.2016.01538.

[6] A. Yahaya, J. Ramli, S. Hashim, M. A. Ibrahim, R. R. R. A. Rahman, and N. Yahaya, "Discipline problems among secondary school students in Johor Bahru, Malaysia,” Eur. J. Soc. Sci., vol. 11, no. 4, pp. 659-675, 2009.

[7] F. Sadik, "Children and discipline: Investigating secondary school students' perception of discipline through metaphors," Eur. J. Educ. Res., vol. 7, no. 1, pp. 31-44, 2018, doi: 10.12973/eu-jer.7.1.31.

[8] T. J. Mowen, J. J. Brent, and J. H. Boman, "The Effect of School Discipline on Offending across Time,” Justice Q., vol. 37, no. 4, pp. 739-760, 2020, doi: 10.1080/07418825.2019. 1625428.

[9] P. Senjaya, F. Kotamena, F. Ong, C. B. Andika, A. Purwanto, and R. Pramono, "School environmental influences, student discipline and learning motivation toward increasing senior high students achievement,” Int. J. Adv. Sci. Technol., vol. 29, no. 5, pp. 4572-4586, 2020.

[10] R. O. Welsh, “Intra-District Student Mobility, School Discipline and Gender: Evidence From Clark County, Nevada,” Educ. Urban Soc., vol. 51, no. 9, pp. 1217-1244, 2019, doi: 10.1177/0013124518785022.

[11] A. Jaelani, Patimah, U. Sanusi, and A. Arifuddin, "The implementation of principal managerial competence for the primary school student discipline," Univers. J. Educ. Res., vol. 7, no. 8, pp. 1832-1838, 2019, doi: 10.13189/ujer.2019.070823. 
[12]R. I. Lumadi, "Taming the tide of achievement gap by managing parental role in learner discipline,” South African $J$. Educ., vol. 39, no. September, pp. 1-10, 2019, doi: 10.15700/saje.v39ns1a1707.

[13] A. Suking, I. A. Razak, and S. Amay, "Fostering Students ' Discipline in Boarding School," in The 1st International Conference on Education, Sciences and Technology, 2020, vol. 3, pp. 84-92.

[14] K. Routhier-Martin, S. K. Roberts, and N. Blanch, "Exploring Mindfulness and Meditation for the Elementary Classroom: Intersections Across Current Multidisciplinary Research,” Child. Educ., vol. 93, no. 2, pp. 168-175, 2017, doi: 10.1080/00094056.2017.1300496.

[15] E. Marheni, S. Afrizal, E. Purnomo, and N. Jermaina, "Evaluation Of Character Education In Senior High Learning Physical Education,” Solid State Technol., vol. 2650-2658, 2020.

[16] M. Leyton-Román, J. J. L. González-Vélez, M. Batista, and R. Jiménez-Castuera, "Predictive model for amotivation and discipline in physical education students based on teachinglearning styles,” Sustain., vol. 13, no. 1, pp. 1-14, 2021, doi: 10.3390/su13010187.

[17] F. Claver, L. M. Martínez-Aranda, M. Conejero, and A. Gil-Arias, "Motivation, Discipline, and Academic Performance in Physical Education: A Holistic Approach From Achievement Goal and Self-Determination Theories," Front. Psychol., vol. 11, no. July, pp. 1-11, 2020, doi: 10.3389/fpsyg.2020.01808.

[18] J. A. V. Lacárcel and J. A. Moreno-Murcia, "Razonesintrínsecas para la disciplinaenestudiantesadolescentes de educaciónfísica," Educ. XX1, vol. 19, no. 2, pp. 317-335, 2016, doi: 10.5944/educXX1.13950.

[19] A. Oudat, "The Supervisory Competencies of Physical Education Supervisors from the Point of View of Physical Education Teachers," Int. J. Hum. Mov. Sport. Sci., vol. 9, no. 2, pp. 185-193, 2021, doi: 10.13189/saj.2021.090204.

[20]Ц. Ж.o. and Г. Т.i, "Determining Purpose of Academic Discipline 'Physical Education' for Future Teachers,” Teoriâ ta Metod. FìičnogoVihovannâ, vol. 7989, no. 3, pp. 14-18, 2016, doi: 10.17309/tmfv.2016.3.1166.

[21]S. R. Sitompul, "Development of tennis serve learning models based on multiple training," Int. J. Hum. Mov. Sport. Sci., vol. 8, no. 6, pp. 11-15, 2020, doi: 10.13189/saj.2020.080702.

[22] J. H. Downing, "Establishing a Discipline Plan in Elementary Physical Education,” J. Phys. Educ. Recreat. Danc., vol. 67, no. 6, pp. 25-30, 1996, doi: 10.1080/07303084.1996.10604 794.

[23] A. Papaioannou, "Goal perspectives, reasons for being disciplined, and self-reported discipline in physical education lessons,” J. Teach. Phys. Educ., vol. 17, no. 4, pp. 421-441, 1998, doi: 10.1123/jtpe.17.4.421.

[24] M. Bej, "Social Skills and Programs of Positive Discipline in School Environment - A Literature Review," Mediterr. J. Soc. Sci., vol. 7, no. 2, pp. 84-87, 2016, doi: 10.5901/mjss.2016.v7n2s1p84.

[25] J. Bin Li, S. S. Bi, Y. E. Willems, and C. Finkenauer, The
Association Between School Discipline and Self-Control From Preschoolers to High School Students: A Three-Level Meta-Analysis, vol. 91, no. 1. 2021.

[26] S. I. Adlya, A. M. Yusuf, and M. Effendi, "The contribution of self control to students' discipline,” J. Couns. Educ. Technol., vol. 3, no. 1, p. 1, 2020, doi: 10.32698/0791.

[27]F. C. Curran, “A Matter of Measurement: How Different Ways of Measuring Racial Gaps in School Discipline Can Yield Drastically Different Conclusions About Racial Disparities in Discipline,” Educ. Res., vol. 49, no. 5, pp. 382387, 2020, doi: 10.3102/0013189X20923348.

[28] E. Marheni, A. S, and E. Purnomo, “Application of Character Building with Physical Education (CBPE),” SuluahBendang J. Ilm. Pengabdi. Kpd. Masy., vol. 20, no. 1, p. 46, 2019, doi: 10.24036/sb.0400.

[29] G. D. Gottfredson, “Schools and Delinquency," Oxford Handb. Juv. Crime Juv. Justice, no. September 2018, pp. 1-29, 2011, doi:10.1093/oxfordhb/9780195385106.013.000 9.

[30] A. A. Payne and K. Welch, "The Centrality of Schools in the Lifecourse: The Case for Focusing on School-Related Influences in Developmental Theory and Research,” Deviant Behav., vol. 37, no. 7, pp. 748-760, 2016, doi: 10.1080/01639625.2015.1071134.

[31] R. Arum and M. Velez, "Improving Learning Environments: School Discipline and Student Achievement in Comparative Perspective," Stanford, CA Stanford Univ. Press, pp. 658660, 2012, doi: doi:10.1177/0094306114545742e.

[32] A. A. Fekadu, “Assessing the Impact of School Rules and Regulations on Students' Perception Toward Promoting Good Behavior: Sabian Secondary School, Dire Dawa, Ethiopia,” Stats, vol. 2, no. 2, pp. 202-211, 2019, doi: $10.3390 /$ stats2020015.

[33] I. Ahmad, M. Rauf, S. Rehman, W. Khan, A. Rashid, and F. Ali, “Teachers' Perceptions of Classroom Management, Problems and its Solutions: Case of Government Secondary Schools in Chitral, Khyber Pakhtunkhwa, Pakistan,” Int. J. Bus. Soc. Sci., vol. 3, no. 24, pp. 173-182, 2012, [Online]. Available:

http://www.ijbssnet.com/journals/Vol_3_No_24_Special_Is sue_December_2012/18.pdf.

[34] A. R. Saidek, RaisulIslami, and Abdoludin, "Character Issues: Reality Character Problems and Solutions through Education in Indonesia,” J. Educ. Pract., vol. 7, no. 17, pp. 158-165, 2016, [Online]. Available: https://eric.ed.gov/?id= EJ1108663.

[35] J. Raible and J. G. Irizarry, “Redirecting the teacher’s gaze: Teacher education, youth surveillance and the school-to-prison pipeline,” Teach. Teach. Educ., vol. 26, no. 5, pp. 1196-1203, 2010, doi: 10.1016/j.tate.2010.02.006.

[36] L. A. Gelles, S. M. Lord, G. D. Hoople, D. A. Chen, and J. A. Mejia, "Compassionate flexibility and self-discipline: Student adaptation to emergency remote teaching in an integrated engineering energy course during covid-19," Educ. Sci., vol. 10, no. 11, pp. 1-23, 2020, doi: 10.3390/educsci10110304.

[37] N. Kyegombeet al., "How did the Good School Toolkit reduce the risk of past week physical violence from teachers 
to students? Qualitative findings on pathways of change in schools in Luwero, Uganda," Soc. Sci. Med., vol. 180, no. March, pp. 10-19, 2017, doi: 10.1016/j.socscimed.2017.03. 008 .

[38] N. A. Rohmaniyah, K. Khamdun, and E. Widianto, “Analysis of Parenting Patterns on Student Motivatio," J. Educ. Technol., vol. 4, no. 3, p. 359, 2020, doi: 10.23887/jet.v4i3.28538.

[39] F. Scalici and P. J. Schulz, "Parents' and peers' normative influence on adolescents' smoking: Results from a Swiss-Italian sample of middle schools students," Subst. Abus. Treat. Prev. Policy, vol. 12, no. 1, pp. 1-9, 2017, doi: 10.1186/s13011-017-0089-2.

[40] M. W. Hodes, M. Meppelder, M. de Moor, S. Kef, and C. Schuengel, "Effects of video-feedback intervention on harmonious parent-child interaction and sensitive discipline of parents with intellectual disabilities: A randomized controlled trial,” Child. Care. Health Dev., vol. 44, no. 2, pp. 304-311, 2018, doi: 10.1111/cch.12506.

[41]M. de Klepper, E. Sleebos, G. van de Bunt, and F. Agneessens, "Similarity in friendship networks: Selection or influence? The effect of constraining contexts and non-visible individual attributes,” Soc. Networks, vol. 32, no. 1, pp. 82-90, 2010, doi: 10.1016/j.socnet.2009.06.003.

[42] L. K. Brendtro and M. Caslor, "The Effectiveness of Positive Peer Culture with Youth at Risk," Glob. J. Human-Social Sci., vol. 19, no. 10, pp. 7-14, 2019, doi: 10.34257/gjhssavol19is10pg7.

[43] L. N. Chukwurah, O. I. Abbah, C. N. Iweama, J. E. Ogugua, and J. Ameh, "Students' achievement in physical and health education: Effect of discussion teaching method," Int. J. Hum. Mov. Sport. Sci., vol. 8, no. 3, pp. 86-90, 2020, doi: 10.13189/saj.2020.080302. 